dr inż. Łukasz Kaczmarek ${ }^{1,2}$

dr hab. Sebastian Kowalczyk, prof. ucz. ${ }^{3}$

dr hab. Radosław Mieszkowski ${ }^{3}$

\title{
REINTERPRETACJA PIONIERSKICH BADAŃ \\ Z WYKORZYSTANIEM PIONOWYCH SONDOWAŃ \\ ELEKTROOPOROWYCH BUDOWY GEOLOGICZNEJ WARSTWY WODONOŚNEJ
}

https://doi.org/10.18778/8220-655-5.06

\begin{abstract}
Streszczenie: Badania geofizyczne dostarczają przestrzennych informacji o zmienności ośrodka gruntowo-skalnego. Wyniki zastosowania tych metod, także archiwalne, warto wykorzystywać w prowadzonych hydrogeologicznych pracach dokumentacyjnych. Takim przykładem są zrealizowane badania rozpoznawcze w miejscowości Łobodno w północno-zachodniej części Wyżyny Śląsko-Krakowskiej zlokalizowanej w granicach GZWP nr 326 Częstochowa (E). Przeprowadzone tam pionowe sondowania elektrooporowe, korelowane z profilami wierceń umożliwiły m.in.: (i) zwiększenie głębokości rozpoznania z ok. 70 do 100-150 m p.p.t. obejmując czwartorzędowe grunty gliniasto-piaszczyste przykrywające górnojurajski kompleks wapieni zalegających na środkowojurajskich iłach i marglach, (ii) identyfikację głębokości zalegania różnych utworów gruntowo-skalnych wraz z określeniem reliefu ich stropu, (iii) wskazanie zmienności litologiczno-strukturalnej w obrębie tych samych wydzieleń, (iv) lokalizację większych dyslokacji, (v) dokładniejsze opisanie warunków przepływu wód podziemnych.
\end{abstract}

Słowa kluczowe: geofizyka, przekrój geoelektryczny, wapienie, ujęcie wody, Łobodno.

\section{Wprowadzenie}

Metody geofizyczne mają szerokie zastosowania w naukach geologicznych oraz inżynierskich (Vogelsang 1995, Loke 2004, Reynolds 2011, Mieszkowski i in. 2014, Tarnawski i in. 2020, Marciniak i in. 2021), a w szczególności w badaniach hydrogeologicznych (Castany 1972, Kirsch 2006, Topolewska i in. 2016). Metody te dostarczają istotnych informacji przy obrazowaniu budowy geologicznej i uwarunkowań hydrogeologicznych w sposób jedno, dwu oraz trójwymiarowy, a także w funkcji czasu. Jednymi z najbardziej popularnych metod w analizie warunków przepływu wód podziemnych są metody elektrooporowe, które właśnie w tym celu zostały opisane przez Wenner'a (1916), a następnie Schlumberger'a (1920). Najczęściej zasięg głębokościowy tych metod wynosi do 100-150 m p.p.t. (Tarnawski i in. 2020). Tabela 1 przedstawia zestawienie wybranych metod geofizycznych stosowanych przy rozpoznawaniu warunków hydrogeologicznych.

\footnotetext{
${ }^{1}$ Politechnika Warszawska, Wydział Instalacji Budowlanych, Hydrotechniki i Inżynierii Środowiska, Zakład Budownictwa Wodnego, ul. Nowowiejska 20, 00-653 Warszawa, lukasz.kaczmarek@pw.edu.pl, ORCID 00000001-5207-3816

${ }^{2}$ Przedsiębiorstwo Wodociągów i Kanalizacji Okręgu Częstochowskiego S.A. w Częstochowie, ul. Jaskrowska 14/20, 42-202 Częstochowa

${ }^{3}$ Uniwersytet Warszawski, Wydział Geologii, Katedra Hydrogeologii i Geofizyki, ul. Żwirki i Wigury 93, 02-089 Warszawa; s.kowalczyk@uw.edu.pl, ORCID 0000-0002-9835-1479; r.mieszkowski@uw.edu.pl, ORCID 00000002-4021-4965
} 
Reinterpretacja pionierskich badań z wykorzystaniem pionowych sondowań elektrooporowych...

Tab. 1. Wybrane metody geofizyczne stosowane w rozpoznaniu hydrogeologicznym

\begin{tabular}{|c|c|c|c|c|c|}
\hline \multirow[b]{3}{*}{$\begin{array}{c}\text { METODA } \\
\text { GEOFIZYCZNA }\end{array}$} & \multicolumn{4}{|c|}{ ROZWIĄZYWANE ZAGADNIENIA DLA ROZPOZNANIA } & \multirow[b]{3}{*}{ KOMENTARZE } \\
\hline & \multicolumn{2}{|c|}{ Osadów piaszczysto-ilastych } & \multicolumn{2}{|c|}{ Litego podłoża } & \\
\hline & $\begin{array}{c}\text { Struktura } \\
\text { osadów } \\
\text { (rodzaj, } \\
\text { miąższość } \\
\text { i następstwo } \\
\text { warstw) }\end{array}$ & $\begin{array}{c}\text { Stopień } \\
\text { zaburzenia } \\
\text { budowy } \\
\text { (ciągłość, upad, } \\
\text { zmienność } \\
\text { wyksztalcenia) } \\
\end{array}$ & $\begin{array}{l}\text { Glębokość } \\
\text { zalegania } \\
\text { i rodzaj } \\
\text { podłoża }\end{array}$ & $\begin{array}{c}\text { Stopień } \\
\text { zaburzenia } \\
\text { budowy } \\
\text { (spękania, } \\
\text { uskoki, } \\
\text { nieciągłości) }\end{array}$ & \\
\hline $\begin{array}{c}\text { Sondowania } \\
\text { elektrooporowe } \\
(V E S, S G E)\end{array}$ & +++ & ++ & ++ & $++/+$ & $\begin{array}{l}\text { Aktualnie pomiary tanie } \\
\text { i relatywnie latwe do } \\
\text { wykonania }\end{array}$ \\
\hline $\begin{array}{c}\text { Tomografia } \\
\text { elektrooporowa } \\
(E R I, E R T) \\
\end{array}$ & +++ & +++ & ++ & ++ & $\begin{array}{l}\text { Pomiary stosunkowo tanie, } \\
\text { ale trudniejsze do wykonania. }\end{array}$ \\
\hline $\begin{array}{l}\text { Sejsmika } \\
\text { refrakcyjna }\end{array}$ & - & - & +++ & +++ & $\begin{array}{c}\text { Metoda kosztowna, ale } \\
\text { najefektywniejsza w badaniu } \\
\text { podłoża skalnego. }\end{array}$ \\
\hline $\begin{array}{l}\text { Georadar } \\
(G P R)\end{array}$ & ++ & ++ & ++ & ++ & $\begin{array}{l}\text { Mały zasięg głębokościowy. } \\
\text { Warstwa gruntów spoistych } \\
\text { przy powierzchni może } \\
\text { uczynić tą metodę } \\
\text { nieefektywną. }\end{array}$ \\
\hline $\begin{array}{c}\text { Pomiary } \\
\text { otworowe } \\
\text { (karotażowe) } \\
\end{array}$ & +++ & ++ & +++ & ++ & $\begin{array}{l}\text { Pomiary w otworach wiertni- } \\
\text { czych w celu ograniczenia } \\
\text { ilości wierceń rdzeniowych. }\end{array}$ \\
\hline
\end{tabular}

Objaśnienia: efektywność metody: +++ duża, ++ średnia, + mała, - metody nie stosuje się

Źródło: opracowano we własnym zakresie - zmodyfikowane za Rodzoch i in. 2006.

Do niedawna, jedną z powszechnie wykorzystywanych metod były pionowe sondowania elektrooporowe (ang. Vertical Electrical Sounding - VES; w Polsce opisywana także skrótami SGE - sondowania geoelektryczne, PSE - pionowe sondowania elektrooporowe). Jest to jednowymiarowa (1D) metoda umożliwiająca nieinwazyjną prospekcję z powierzchni terenu, której wyniki z poszczególnych pomiarów można zestawić w postaci przekroju geoelektrycznego. Metoda ta obecnie jest coraz częściej wypierana przez metodę tomografii elektrooporowej, nazywaną także metodą obrazowania elektrooporowego, pozwalającą na bardziej efektywne obrazowanie $2 \mathrm{D}$ oraz $3 \mathrm{D}$.

Metody elektrooporowe polegają na pomiarach parametrów sztucznie wywołanego pola elektrycznego w ośrodku gruntowo-skalnym. Takim podstawowym parametrem jest oporność utworów geologicznych, której jednostką jest omometr $(\Omega \mathrm{m})$. Oporność górotworu cechuje się znacznym zróżnicowaniem, gdzie utwory zawodnione mają najniższe oporności (w przypadku zasolonych utworów nawet pojedyncze omometry), a utwory suche mogą cechować się wartościami kilkudziesięciu tysięcy omometrów (np. wydmowe piaski suche, nasypy przesuszone, czy skały pochodzenia chemicznego). Wartości oporności takich samych litologicznych gruntów i skał (o zbliżonym składzie mineralnym) są różnicowane przez wilgotność, mineralizację wody, porowatość oraz przepuszczalność, zailenie, a także temperaturę. Parametr oporności stanowi zatem wypadkową właściwość fizyczną materiału. Dzięki dużej zmienności, szczegółowa interpretacja rezultatów prospekcji elektrooporowej, umożliwia m.in. jakościowe i ilościowe kartowanie budowy geologicznej - w tym głębokości stropu bedrock oraz poszukiwania 
warstw wodonośnych (Tarnawski i in. 2020). Określanie miąższości warstw wodonośnych, obecności wody, rozciągłości warstw zawodnionych oraz ich możliwych strukturalnych dróg kontaktu, z płycej i głębiej położonymi utworami przepuszczalnymi, jest szczególnie istotne w przypadku użytkowych poziomów wód podziemnych, wykorzystywanych przez przedsiębiorstwa wodociągowe jako zasobny rezerwuar wysokiej jakości wód przeznaczanych do spożycia przez ludzi.

Poniżej przedstawiono wybrane, pionierskie w Polsce, archiwalne wyniki badań pionowych sondowań elektrycznych (z 1968 r.). Rezultaty przeanalizowano w odniesieniu do tradycyjnie wykonywanych prac dokumentacyjnych. Opisane możliwości badań geofizycznych zostały przedstawione na przykładzie rejonu m. Łobodno (północny-zachód od Częstochowy), gdzie lokalizowane są m.in. komunalne ujęcia wód podziemnych.

\section{Region badań}

Rejon Łobodna administracyjnie położony jest w powiecie kłobuckim, natomiast morfologicznie należy do Wyżyny Wieluńskiej, będącej północno-zachodnią częścią Wyżyny Śląsko-Krakowskiej (Kondracki 2000). Rzeźba terenu cechuje się występowaniem pojedynczych wzniesień ostańcowych (zbudowanych z wapieni górnej jury - Bednarek i in. 1987, Kaziuk i Nowak 1999). Rzędne terenu kształtują się na ogół na poziomie 225-240 m n.p.m. Lokalnie, w miejscach wzniesień ostańców, rzędne mogą dochodzić do 275 m n.p.m., a w dolinie rzeki Białej Okszy wynoszą ok. 210 m n.p.m. Powierzchnia terenu zapada na północny-wschód.

Prezentowane badania geofizyczne zostały przeprowadzone dla ujęcia górnojurajskich wód podziemnych. Rejon ten położony jest w zlewni Warty i w granicach GZWP nr 326 Częstochowa (E) - ryc. 1. W artykule skupiono się na zestawieniu wyników analizy w obszarze otworu nr 3 położonego na rzędnej 227,5 m n.p.m.

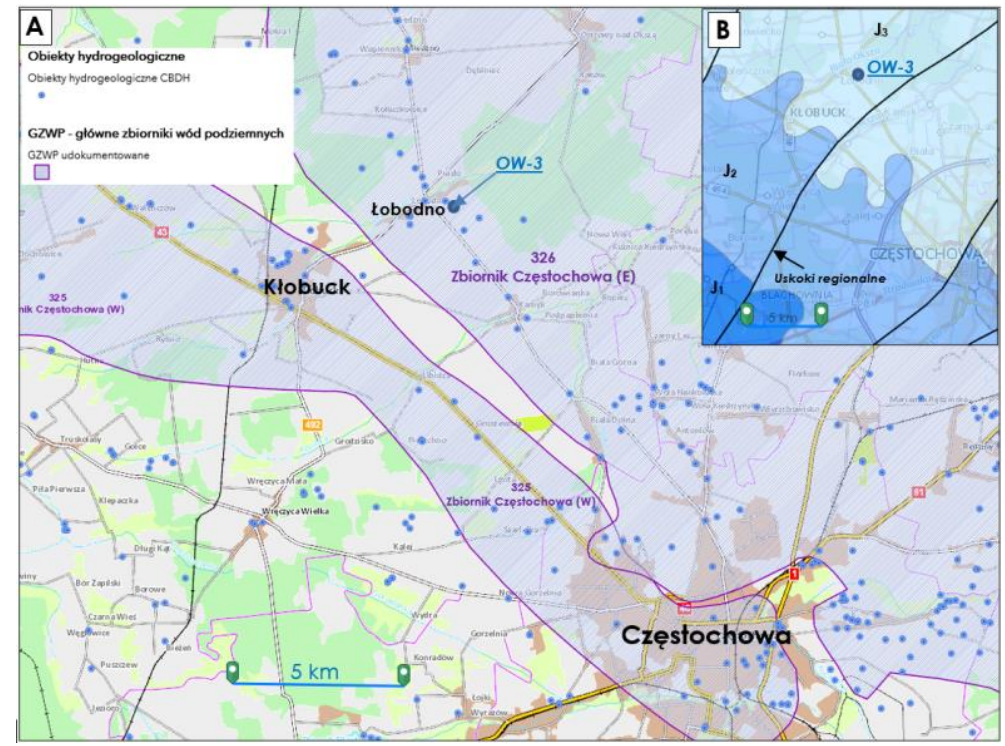

Ryc. 1. Mapa lokalizacyjna (A) oraz fragment mapy geologicznej bez utworów kenozoiku (B) analizowanego rejonu $\mathrm{w} \mathrm{m}$. Łobodno

Źródło: Portal mapowy Geologia, PIG-PIB 
Reinterpretacja pionierskich badań z wykorzystaniem pionowych sondowań elektrooporowych...

\section{Budowa geologiczna}

Analizowany obszar, zgodnie z geologicznym podziałem Polski oraz opisem przedstawionym w objaśnieniach do szczegółowych map geologicznych Polski - arkusze 808 i 809 (Bednarek i in. 1992, Kaziuk i Nowak 2014), jest położony w granicach mezozoicznej struktury Monokliny Śląsko-Krakowskiej o rozciągłości północny-zachód a południowy-wschód (zapadającej pod niewielkim nachyleniem na północny-wschód). Monoklina Śląsko-Krakowska zbudowana jest z utworów triasu i jury. Trias dolny i środkowy składa się z facji węglanowej, trias górny z facji ilastych. W oparciu o wyniki wierceń (Hermański i in. 2005) oraz szczegółowe mapy geologiczne Polski (Bednarek i in. 1992, Kaziuk i Nowak 2014) można stwierdzić, że strop utworów triasowych położony jest na głębokości ok. 400 m. Powyżej zalegają utwory jury dolnej (głównie warstwy piaskowców). Następnie występują utwory jury środkowej (tzw. dogger) o łącznej miąższości ok. $200 \mathrm{~m}$. W spągu tych utworów, obecne są utwory piaszczysto-piaskowcowe stanowiące poziom wodonośny - tzw. „warstwy kościeliskie” o miąższości ok. $30 \mathrm{~m}$ (aalen i bajos dolny). Powyżej, obecne są izolujące skały ilaste (rudonośne) bajosu górnego i batonu o bardzo dużej miąższości (ok. $170 \mathrm{~m}$ ), nad którymi występują płytowe wapienie piaszczyste przewarstwione marglami keloweju (o miąższości tutaj ok. $15 \mathrm{~m}$ ). Powyżej zalegają osady jury górnej (malm), które w okolicach Łobodna wykształcone są w postaci wapieni skalistych i płytowych (oksford). Udział wapieni skalistych, które cechują się zeszczelinowaniem i obecnością krasu, wraz z głębokością wzrasta. Miąższość górnojurajskich utworów $\mathrm{w}$ analizowanym rejonie jest w przybliżonym zakresie od 50 do $100 \mathrm{~m}$. Powierzchnia stropu jury górnej (w rejonie Łobodna rzędne od ok. 205 m n.p.m. do 235 m n.p.m.) jest silnie rozwinięta, co wynika z historycznej aktywności ruchów tektonicznych, a w późniejszym czasie wietrzenia i erozji (także glacjalnej). Jura górna cechuje się strukturą zrębowo-rowową, gdzie uskoki (najczęstszy przebieg z południowego-zachodu na północny-wschód) ułatwiają powstawanie sieci spękań wapieni jury górnej (Bednarek i in. 1992, Kaziuk i Nowak 2014).

Struktura Monokliny Śląsko-Krakowskiej przykryta jest czwartorzędowymi osadami, takimi jak np. wodnolodowcowe i rzeczne piaski, lodowcowe gliny piaszczyste, czy gliny z okruchami wapieni oraz miejscowo występującymi osadami rzecznymi. Utwory te mają przeważnie niewielką miąższość, natomiast w dolinach miąższość dochodzi do ok. 40 m.

\section{Warunki hydrogeologiczne}

$\mathrm{Na}$ analizowanym obszarze występuje czwartorzędowe piętro wodonośne, w którym zwierciadło wody zalega na głębokości kilku metrów. Kierunek przepływu wód czwartorzędowych jest zgodny z kierunkiem przepływu Białej Okszy, tj. na północny-wschód (Liszka i in. 2006). Użytkowe znaczenie ma szczelinowo-krasowy górnojurajski poziom wodonośny cechujący się napiętym zwierciadłem (głównie przez gliniaste utwory czwartorzędowe) na przybliżonej rzędnej ok. 220 m n.p.m. (Dziuk i Będkowski 1997, Liszka i in. 2000). Dominujące kierunki przepływu górnojurajskich wód podziemnych w rejonie otworu nr 3 to z południowego-zachodu na północny-wschód oraz z południa na północ. Zasilanie tego poziomu następuje poprzez infiltrację wód opadowych. W ujęciu regionalnym izolacja górnojurajskiego poziomu wodonośnego nie jest ciągła, co w efekcie występowania także uskoków w skali regionalnej i lokalnej umożliwia mieszanie się przypowierzchniowych wód z wodami górnojurajskimi. 


\section{Metodyka}

W metodach elektrooporowych celem rozpoznania jest przestrzeń ośrodka geologicznego, do którego został wprowadzony prąd stały za pomocą pary elektrod (np. A i B). Jednocześnie, za pomocą dwóch kolejnych elektrod (np. M i N) rejestrowany jest spadek napięcia, będący proporcjonalnym do oporności elektrycznej ośrodka oraz rozstawu elektrod (wzajemna konfiguracja położenia i odległości $\mathrm{w}$ układzie wyznaczanym lokalizacją elektrod zasilających i pomiarowych). Rozstaw elektrod musi zostać wcześniej zdefiniowany. Jednym z najpopularniejszych układów w technice VES jest układ Schlumberger’a (ryc. 2). Wynika to z wiarygodności wyników prospekcji oraz dokładności pomiarowej (tab. 3). Aspekty techniczne wraz ze szczegółowym opisami metodyki zostały przedstawione m.in. przez Stenzela i Szymanko (1973), jak również w przekrojowym opracowaniu zbiorowym pod redakcją Tarnawskiego (2020).

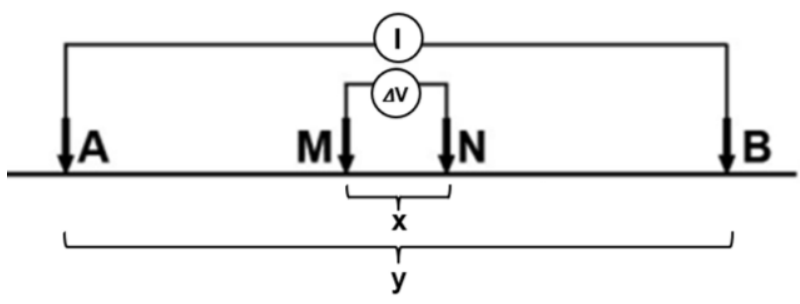

Ryc. 2. Przestrzenny rozstaw elektrod układu Schlumberger'a, który został zastosowany w opisywanych badaniach

Objaśnienia: A, B - elektrody prądowe; M, N - elektrody pomiarowe; I - natężenie prądu wprowadzonego do gruntu przez elektrody $\mathrm{A}, \mathrm{B} ; \Delta \mathrm{V}$ - różnica potencjałów elektrycznych mierzona między elektrodami M i N; $\mathrm{x}, \mathrm{y}$ - odległości między elektrodami, gdzie $\mathrm{x} \leq 1 / 3 \mathrm{y}$

$$
\text { Źródło: opracowanie własne }
$$

Pionowe sondowania elektrooporowe prowadzono w rejonie Łobodna od 18.06 do 30.07 1968 r. (tj. 43 dni), w czasie których zrealizowano kilkadziesiąt pionowych sondowań. Badania te zrealizowane były przez Przedsiębiorstwo Poszukiwań Geofizycznych (PPG) na rzecz (aktualnie) Przedsiębiorstwa Wodociągów i Kanalizacji Okręgu Częstochowskiego SA w Częstochowie. Sondowania przeprowadzono z zastosowaniem wcześniej wymienionego układu symetrycznego Schlumberger'a - w pierwszej kolejności wzdłuż linii I przy już istniejących otworach wiertniczych. Dzięki temu uzyskano wartości referencyjne oporności skorelowane z dokładnie rozpoznanymi utworami wodonośnymi. W następnym etapie, wzdłuż linii zagęszczono miejsca sondowań między otworami archiwalnymi wykonując badania w odległości co ok. $200 \mathrm{~m}$. Kolejne dwie linie przekroju poprowadzono równolegle do pierwszej linii, natomiast ostatni ciąg pomiarowy prostopadle do trzech pierwszych. Te cztery ciągi sondowań (ryc. 3), wytyczane z wykorzystaniem teodolitu oraz taśmy stalowej miały łączną długość $12 \mathrm{~km}$. Harmonogram prac pozwolił na dostosowywanie lokalizacji ciągów pomiarowych do budowy geologicznej oraz położenia uskoków. Rozstaw elektrod A i B dochodził do $1500 \mathrm{~m}$. W pomiarach wykorzystano polowy kompensator elektronowy typu PKE, linie pomiarowe i zasilające z kabli typu Glx, elektrody stalowe i miedziane oraz źródło zasilania w postaci suchych baterii anodowych. Zbliżone komponenty wykorzystuje się we współcześnie produkowanych systemach pomiarowych VES. 
Reinterpretacja pionierskich badań z wykorzystaniem pionowych sondowań elektrooporowych...

Na rycinie 3 przedstawiono reinterpretacje jednego fragmentu głównego przekroju geoelektrycznego nr 1 (o długości $\sim 2$ km i głębokości prospekcji $\sim 150 \mathrm{~m}$ ) przy otworach nr: 2, 3 i 8. Otwór nr 3 aktualnie wykorzystywany jest jako studnia głębinowa. Przekroje geoelektryczne stanowią finalny rezultat prac interpretacyjnych wielu wyników pojedynczych pionowych sondowań elektrooporowych w postaci krzywych opornościowych. Reinterpretowany przekrój geoelektryczny zestawiono z przykładowym przekrojem hydrogeologicznym, który mógłby być wykonany w przypadku braku znajomości wyników badań geofizycznych. Z powodów m.in. aspektów finansowych zrealizowane badania dla celów hydrogeologicznych w takiej skali nie są, nawet współcześnie, często spotykane.

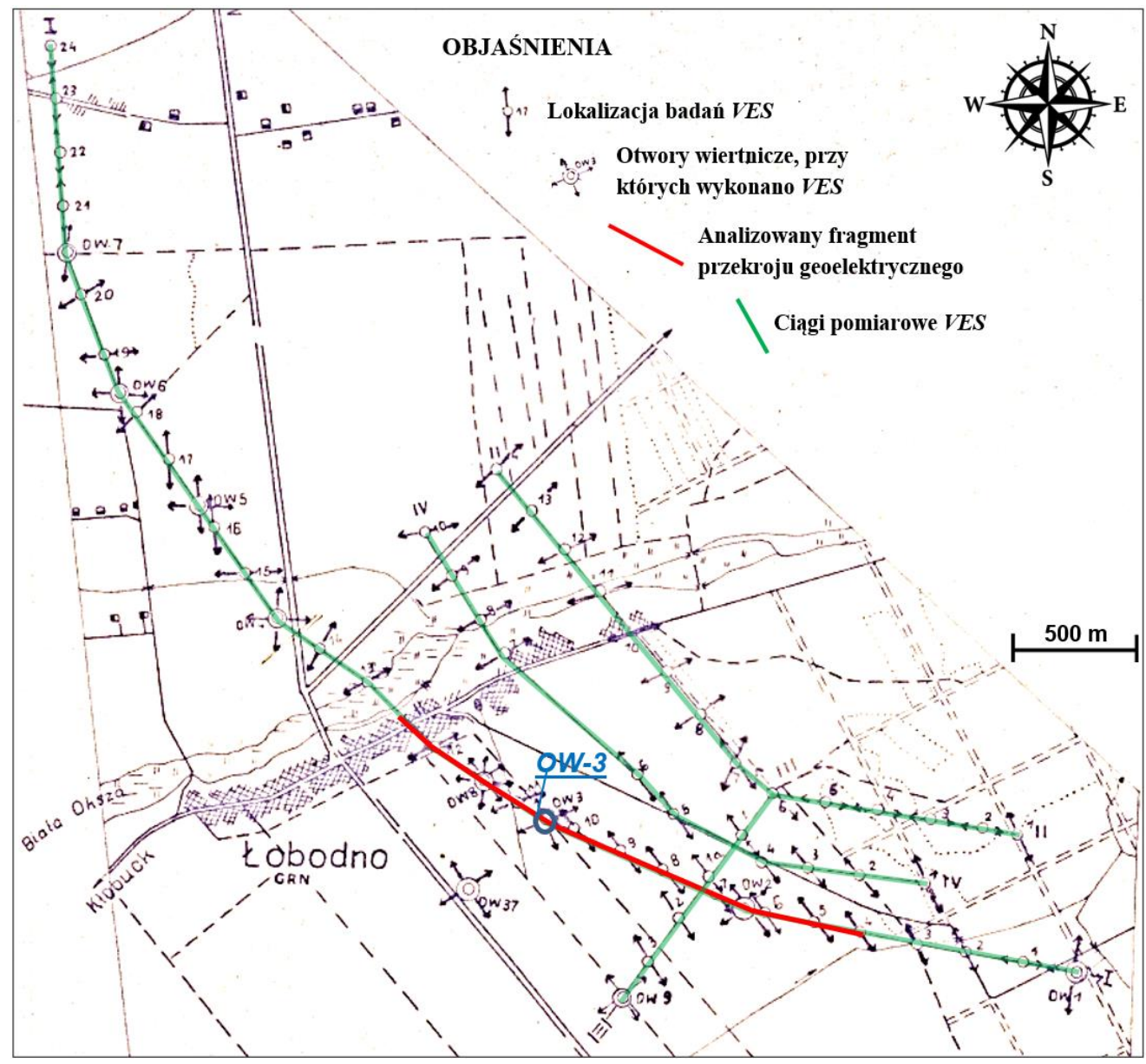

Ryc. 3. Lokalizacja badań VES na tle mapy topograficznej

Źródło: zmodyfikowano w oparciu o opracowanie PPG (1968)

\section{Wyniki badań}

Rezultaty przeprowadzonych pionowych sondowań elektrooporowych stanowią jednowymiarowe krzywe oporności pozornej w funkcji długości rozstawu elektrod ,prądowych” (AB/2). W analizowanym odcinku ciągu badań $V E S$ zrealizowano 12 takich sondowań, z których trzy to sondowania parametryczne, tzn. wykonane w pobliżu otworów wiertniczych (nr: 2, 3 i 8). 
Zestawienie wyników sondowań elektrooporowych z profilem wiertniczym jest dużą zaletą przeprowadzonych badań, ponieważ wyniki VES nie zawsze są jednoznaczne (Stenzel i Szymanko 1973, Tarnowski 2020). Istotnym uzupełnieniem tego typu badań mógłby być także karotaż elektryczny (Stenzel i Szymanko 1973).

Dane zarejestrowane, w trakcie pomiarów terenowych, poddano etapowemu przetwarzaniu z wykorzystaniem specjalistycznych procedur, czego efektem było uzyskanie najpierw wyinterpretowanej i przetworzonej krzywej VES (oporności pozornej w funkcji rozstawu AB), a następnie wartości oporności w przedziale głębokości (profili geoelektrycznych). Rycina 4 przedstawia dwa wynikowe wykresy tego samego sondowania elektrooporowego z przetwarzaniem krzywej VES, wykonanego w środkowej części analizowanego ciągu pomiarowego przy otworze OW-3.

Pierwszy wykres z ryc. 4 obejmuje pierwotnie wykonaną interpretację, natomiast drugi jego aktualną reinterpretację. Między obiema interpretacjami minęło wiele lat, co przekłada się na zastosowanie różnych technik interpretacyjnych. Pierwsza odbyła się poprzez „dopasowanie" krzywej pomiarowej do zestawu krzywych teoretycznych. Druga natomiast jest efektem inwersji wykonanej w programie IPI2win. Zauważalne różnice w interpretacji dotyczą głębokości położenia granic między warstwami litologicznymi (skorelowanymi z przetworzoną krzywą VES), miąższości warstw oraz szczegółowości uzyskanego obrazu opornościowego w górnej i dolnej strefie sondowania.

Dzięki połączeniu 12. wykonanych profili geoelektrycznych w analizowanym fragmencie ciągu otrzymano przekrój geoelektryczny (ryc. 5.B). Dla uwypuklenia korzyści płynących z wykonanych badań geofizycznych na ryc. 5.A przedstawiono zgeneralizowany przekrój geologiczny, który wykonano wyłącznie w oparciu o profile wierceń pozyskane z Narodowego Archiwum Geologicznego.

W budowie geologicznej analizowanego obszaru można wskazać iły, iły piaszczyste i margle na rzędnych 150-160 m n.p.m. (głębokości poniżej 70 m) jury środkowej. Powyżej położone są zawodnione utwory jury górnej - wapienie skaliste i płytowe, gdzie mogą rozwijać się procesy szczelinowania i krasu. Bliżej stropowej powierzchni obecne są także górnojurajskie spoiste utwory zwietrzelinowe oraz wapienie margliste, które napinają zwierciadło wód podziemnych. Stropowa powierzchnia górnojurajskich utworów różnicuje się $\pm 20 \mathrm{~m}$, tworząc w rejonie otworu nr 2 wyniesienie.

Powierzchniowo zalegające utwory czwartorzędowe mają miąższość 20-30 m i w południowo-wschodnim rejonie (otwory nr 1 i 2) to głównie grunty gliniaste i piaszczyste, natomiast w północno-zachodniej części opisywanego przekroju znajdują się głównie utwory piaszczyste. W pierwszym rejonie występuje kilka lokalnych zwierciadeł wód gruntowych, natomiast w drugim rejonie obecne jest najczęściej jedno. Najmniejszy stopień izolacji głównego użytkowego górnojurajskiego poziomu wodonośnego znajduje się w pobliżu otworu nr 2.

Przeprowadzone sondowania VES umożliwiły uszczegółowienie budowy geologicznej oraz zwiększenie jego głębokości rozpoznania, co jest szczególnie istotne w ośrodku: (i) o zmieniającej się strukturze wynikającej z genezy, (ii) zróżnicowanym litologicznie, (iii) w którym występują procesy szczelinowania i krasowienia, (iv) oraz zaangażowanego tektonicznie. 
Reinterpretacja pionierskich badań z wykorzystaniem pionowych sondowań elektrooporowych...

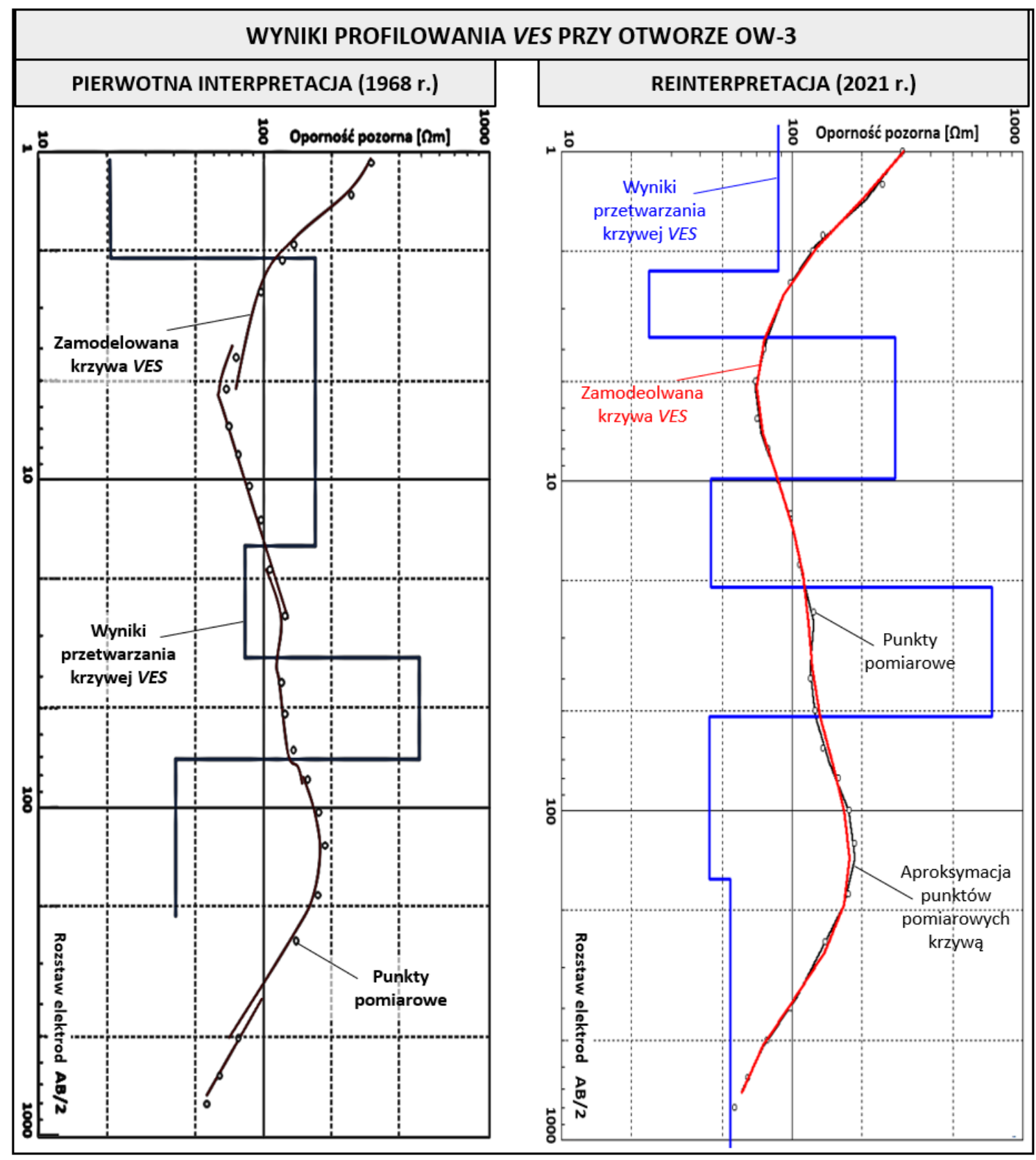

Ryc. 4. Zestawienie przykładowej interpretacji wyników profilowania VES przy OW-3 w Łobodnie $\mathrm{z}$ aktualną reinterpretacją

Źródło: zmodyfikowano w oparciu o opracowanie PPG (1968) 
Łukasz Kaczmarek, Sebastian Kowalczyk, Radosław Mieszkowski

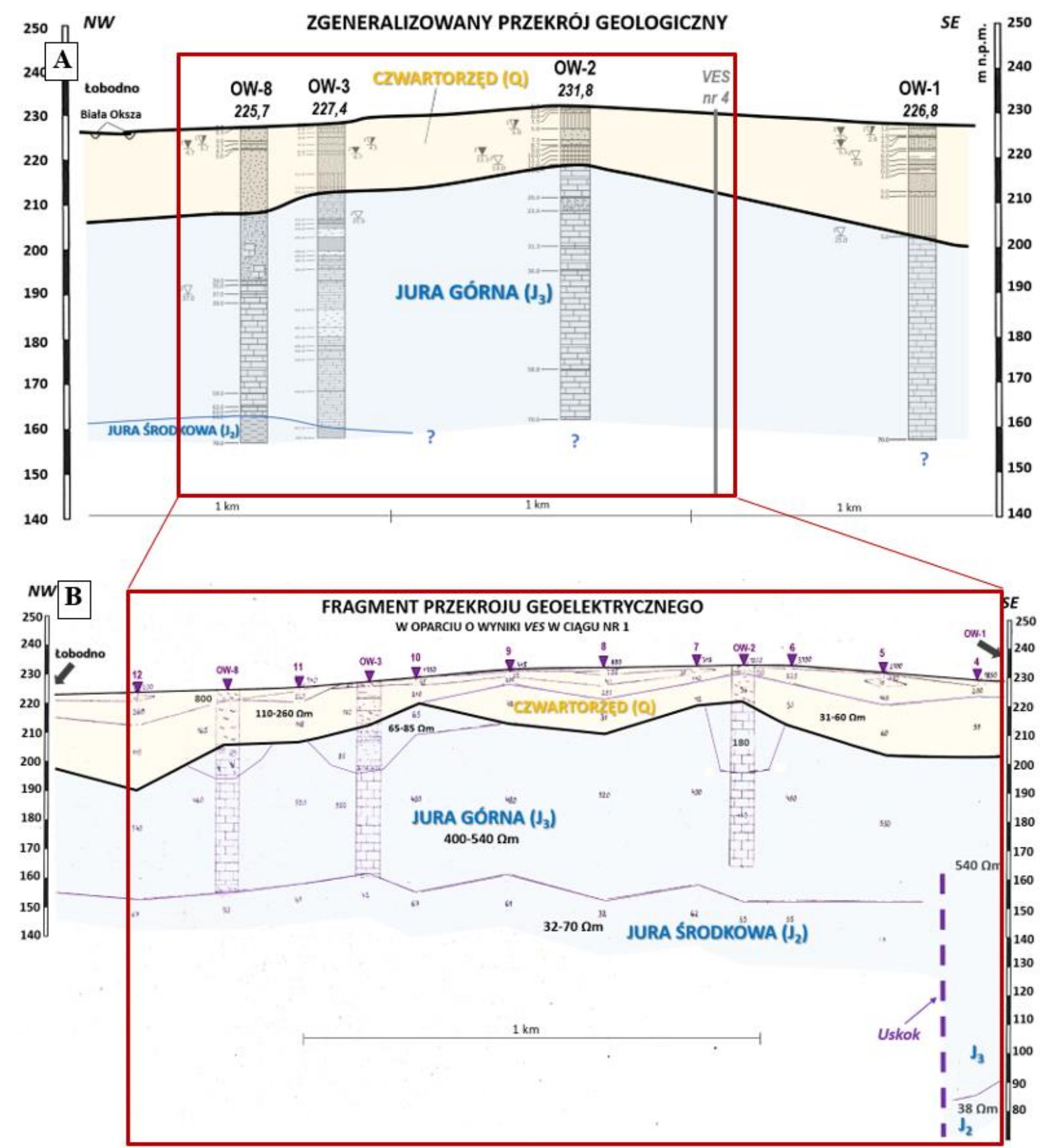

Ryc. 5. Przekrój geologiczny na analizowany odcinku (A);

fragment przekroju geoelektrycznego w rejonie Łobodna (B)

Źródło: zmodyfikowano w oparciu o opracowanie PPG (1968)

Przekrój geoelektryczny przedstawiony na ryc. 5.B odsłania:

- bardziej zróżnicowaną powierzchnię stropową niż zgeneralizowany przekrój geologiczny (ryc. 5.A), gdzie między otworami nr 2 i 3, w rejonie sondowania VES nr 8 można wyszczególnić kilkunastometrowe zagłębienie erozyjne górnojurajskich wapieni 
Reinterpretacja pionierskich badań z wykorzystaniem pionowych sondowań elektrooporowych...

wypełnione utworami spoistymi, na których położone są utwory piaszczyste przewarstwione glinami. Podobna sytuacja występuje w pobliżu sondowania nr 12, aczkolwiek wartości opornościowe wskazują na bardziej dominujący udział utworów piaszczystych. Wyniesienia i obniżenia stropu zawodnionych utworów górnojurajskich mogą korespondować z występowaniem systemów otwartych szczelin powodujących wysokie wydajności studni, tak jak ma to miejsce np. w przypadku pozytywnej próby ujęcia wód podziemnych otworem nr 2 i negatywnej próby w przypadku otworu nr 1;

- obecność uskoku w utworach jurajskich między otworem nr 1 i 2 oraz między sondowaniem VES nr 4 i 5. Ta obecność uskoku potwierdzona jest, udokumentowanymi w tym rejonie, innymi uskokami (Hermański i in. 2005);

- oszacowanie utworów poniżej głębokości wierceń (ok. 70 m) - zasięg prospekcji 100 $150 \mathrm{~m}$. Dzięki temu w przypadku wiercenia nr 2 stwierdzono występowanie stropu środkowojurajskich margli, a dalej na południowy-wschód zmianę miąższości wapieni górnojurajskich związaną z wcześniej wymienioną dyslokacją;

- $\quad$ w glinach czwartorzędowych, udział innych gruntów (oporność wzrasta wraz z ilością piasku, żwiru oraz rumoszu). Natomiast w utworach górnojurajskich wykorzystana metoda pozwoliła na zgeneralizowane wykrycie zwietrzeliny wapieni, obecności margli czy dyslokacji w postaci obniżonych wartości oporności. W tab. 2 przedstawiono zmienność litologiczną utworów na badanym obszarze w nawiązaniu do ich charakterystyk opornościowych. W odniesieniu do literaturowych zestawień i archiwalnych charakterystyk opornościowych najczęściej spotykanych w Polsce można stwierdzić, że zarejestrowane wyniki mieszczą się w ich zakresach.

Tab. 2. Wyniki prospekcji geoelektrycznej na tle literaturowych i archiwalnych wartości oporności wybranych gruntów, skał i innych mediów

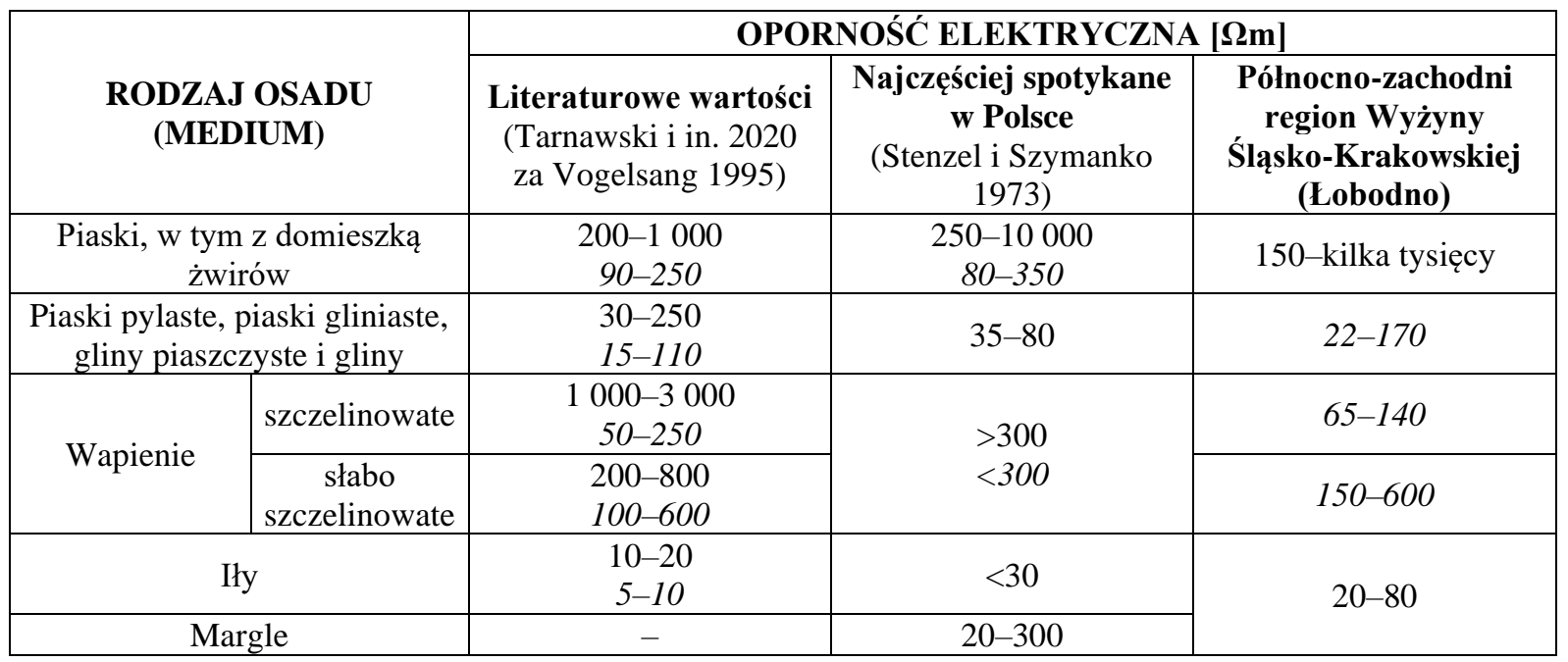

Objaśnienia: wartości podane bez kursywy dotyczą strefy aeracji, kursywa dotycza strefy saturacji

Źródło: w oparciu o opracowania PPG 1968, Stenzel i Szymanko 1973, Tarnawski i in. 2020. 
Zastosowana metoda pionowych sondowań elektrooporowych znacząco uszczegóławia rozpoznanie geologiczne, co wyraźnie widać przy porównaniu przekroju geologicznego z przekrojem geoelektrycznym na ryc. 5. Wykonana szczegółowa analiza wyników oraz dokładna interpretacja pozwala na przestrzenne ilustrowanie zmienności budowy geologicznej (ryc. 6). $\mathrm{Na}$ obszarze badań połączenie to pozwoliło wykazać występowanie uskoków.

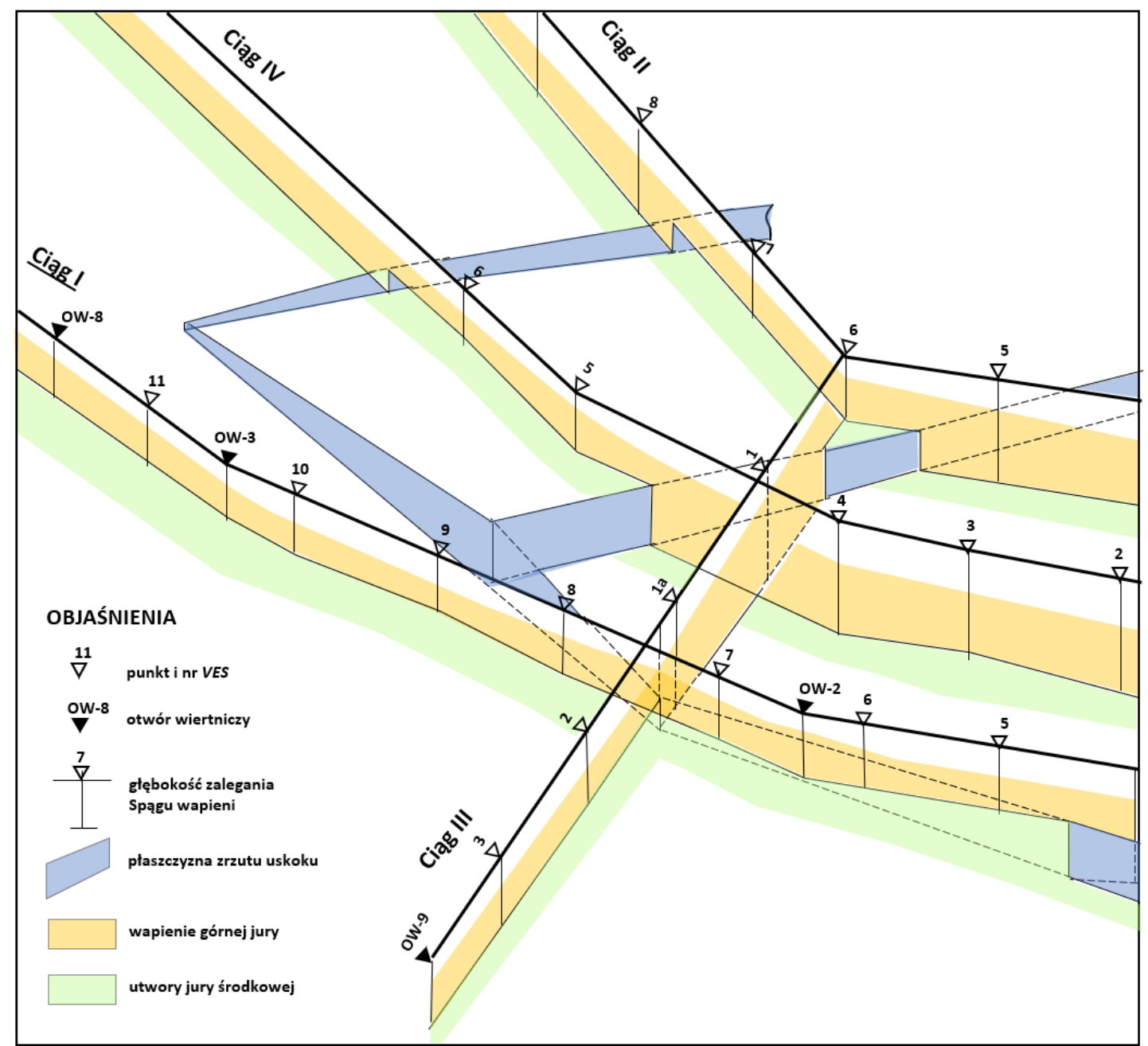

Ryc. 6. Archiwalne przestrzenne zestawienie przekroi geoelektrycznych opartych o wyniki pionowych sondowań elektrooporowych w rejonie Łobodna

Źródło: zmodyfikowano w oparciu o opracowanie PPG (1968)

\section{Podsumowanie}

Jedne z pierwszych badań z wykorzystaniem pionowych sondowań elektrooporowych w Polsce (wykonanych przez Przedsiębiorstwo Poszukiwań Geofizycznych w 1968 r.) przeprowadzonych w rejonie $\mathrm{m}$. Łobodno, $\mathrm{k}$. Częstochowy objęły duży obszar rozszerzając i uszczegóławiając dotychczasowe rozpoznanie budowy geologicznej i warunków hydrogeologicznych na podstawie wierceń. Rejon ten jest położony w granicach Głównego Zbiornika Wód Podziemnych 
Reinterpretacja pionierskich badań z wykorzystaniem pionowych sondowań elektrooporowych...

nr 326 Częstochowa (E). Pomimo tego, z powodu złożonej budowy geologicznej i występujących dyslokacji, nie wszystkie wiercenia rozpoznawczo-badawcze mogły być wykorzystane jako komunalne studnie głębinowe ujmujące górnojurajski poziom wodonośny.

Badania elektrooporowe umożliwiły m.in.: (i) zwiększenie głębokości rozpoznania z ok. 70 m do 100-150 m p.p.t., (ii) uszczegółowienie głębokości zalegania różnych utworów litologicznych wraz z oszacowaniem relifu ich stropu, (iii) wskazanie zmienności litologiczno-strukturalnej w obrębie samych wydzieleń, (iv) lokalizację większych dyslokacji, (v) dokładniejsze opisanie warunków przepływu czwartorzędowych oraz górnojurajskich wód podziemnych.

Przeprowadzona analiza archiwalnych wyników badań wskazuje na dużą przydatność pomiarów elektrooporowych $\mathrm{w}$ rozpoznaniu ośrodka geologicznego, a połączenie kilku metod badań pozwala uzyskać bardziej wiarygodne odwzorowanie rzeczywistych warunków geologicznych.

\section{Bibliografia}

Bednarek J., Haisig J., Lewandowski J., Wilanowski S., 1992, Szczegółowa Mapa Geologiczna Polski arkusz Kłobuck, PIG-PIB, Warszawa.

Castany G., 1972, Poszukiwanie i eksploatacja wód podziemnych, Wyd. Geologiczne, Warszawa.

Dziuk M., Będkowski Z., 1997, Mapa Hydrogeologiczna Polski - arkusz Kłobuck, PIG-PIB, Warszawa.

Hermański S., Nikiel G., Hermańska-Nikiel D., 2005, Dokumentacja hydrogeologiczna ustalająca zasoby eksploatacyjne dla wielootworowego ujęcia wód podziemnych z utworów jury górnej w rejonie Łobodna koło Kłobucka, Geobios, Częstochowa.

Kaziuk H., Nowak B., 2014, Szczegółowa Mapa Geologiczna Polski - arkusz Ostrowy, PIGPIB, Warszawa.

Kirsch R., 2006, Groundwater Geophysics. A Tool for Hydrogeology, Druga edycja, Springer, Berlin.

Kondracki J., 2000, Geografia regionalna Polski, Wyd. Naukowe PWN, Warszawa.

Liszka P., Guzik M., Zembal M., 2000, Mapa Hydrogeologiczna Polski-arkusz Ostrowy, PIGPIB, Warszawa.

Liszka P., Guzik M., Pacholewski A., 2006, Mapa Hydrogeologiczna Polski-Pierwszy poziom wodonośny, arkusz Ostrowy, PIG-PIB, Warszawa.

Loke M.H., 2004, Tutorial: 2-D and 3-D electrical imaging surveys, https://sites.ualberta.ca/ unsworth/UA-classes/223/loke_course_notes.pdf (dostęp: 22.08.2021).

Marciniak A., Kowalczyk S., Gontar T., Owoc B., Nawrot A., Luks B., Cader J., Majdański M., 2021, Integrated geophysical imaging of a mountain landslide - a case study from the Outer Carpathians, Poland, Journal of Applied Geophysics, 191.

Mieszkowski R., Kowalczyk S., Barański M., Szczepański T., 2014, Zastosowanie metod geofizycznych do rozpoznania powierzchni stropowej gruntów słaboprzepuszczalnych oraz wyznaczenia stref rozluźnienia w korpusie zapory ziemnej, Zeszyty Naukowe Instytutu Gospodarki Surowcami Mineralnymi i Energią PAN, 86: 167-180. 
Przedsiębiorstwo Poszukiwań Geofizycznych, 1968, Dokumentacja badań geoelektrycznych - temat: Łobodno, Warszawa.

Reynolds J.M., 2011, An Introduction to Applied and Environmental Geophysics, Druga edycja, Wiley-Blackwell, Chichester.

Rodzoch A., Kuśmierz A., Sawicka-Siarkiewicz H., Borzyszkowski J., Bestyński Z., Dobkowska A., Górka J., Kruk L., Leśniak J., Oficjalska H., Pacholewski A., Tkaczyk A., 2006, Zasady sporzadzania dokumentacji określajacych warunki hydrogeologiczne $w$ związk z projektowaniem dróg krajowych $i$ autostrad - poradnik metodyczny, Instytut Ochrony Środowiska, Warszawa.

Schlumberger C., 1920, Etude sur la Prospection Electrique du Sous-sol., Gauthier-Vilars, Paris.

Stenzel P., Szymanko J., 1973, Metody geofizyczne $w$ badaniach hydrogeologicznych i geologiczno-inżynierskich, Wyd. Geologiczne, Warszawa.

Tarnawski M., Frankowski Z., Godlewski T., Kłosiński J., Mieszkowski R., Nowosad A., Saloni J., Słabek A., Szczepański T., Ura M., Wierzbicki J., Wójcik M., 2020, Badanie podłoża budowli - metody polowe, Wyd. Naukowe PWN, Warszawa.

Topolewska S., Stępień M., Kowalczyk S., 2016, Mapping of the north-eastern part of Kozłowicka buried valley based on geoelectrical data, Studia Quaternaria, 33(2): 91-101.

Wenner F., 1916, A method of measuring earth resistivity, Bulletin of US Bureau of Standards, 12: 469-478.

Vogelsang D., 1995, Environmental geophysics - a practical guide, Springer-Verlag, Berlin. 